MedieKultur | Journal of media and communication research | ISSN 1901-9726

\title{
Oluf Danielsen
}

\author{
Jakob Linaa Jensen og Jesper Tække (red.): \\ Facebook - fra socialt netvark til metamedie. \\ Frederiksberg: Samfundslitteratur, 2013
}

MedieKultur 2014, 57, 200-202

\section{Published by SMID | Society of Media researchers In Denmark | www.smid.dk The online version of this text can be found open access at www.mediekultur.dk}

Facebook er det mest udbredte sociale medie i Danmark, idet mere end halvdelen af den danske befolkning har en profil her. Bogen fremtræder som en bredt anlagt introduktion til Facebook, inddelt i tre dele. Første del, "Facebook som mediefænomen", og anden del, "Facebook og sociale relationer", samt tredje del, "Facebook og samfundet". I de tre kapitler i første del følger vi Facebooks historie og udvikling som et nyt medie. I fire kapitler i anden del er fokus på kommunikation mellem venner og identitetsdannelse. Tredje dels fire kapitler behandler Facebook som et nyt medie i den politiske offentlighed med udfordringer for journalister og mange andre producenter. Fra starten var den interpersonelle kommunikation det centrale, men som bogen viser, er Facebook vokset ud over disse grænser, uden det dog har udkonkurreret den oprindelige anvendelse, i hvert fald endnu.

Facebook er blevet mediet, hvorigennem mange mennesker holder kontakt med et antal venner. Det drejer sig om rigtige venner, dvs. dem man kender i forvejen fra samvær i hverdagen, til festlige sammenkomster og daglige træf i skolen og på arbejdspladsen. De kan holde kontakt med hinanden, i tiden imellem de ses; men hertil kommer så Facebookvennerne, altså typisk mennesker, man tidligere havde kontakt med, eller folk, man har sagt ja til eller opfordret til at være venner med via Facebook. Under overfladen holder Facebook øje med de enkeltes aktiviteter, og blandt andet kan det lede til, at den enkelte også bliver venner med nogle af sine "venners venner". Det kan med andre ord blive en ret stor "vennekreds", den enkelte person kan få på denne måde, hvorfor en del mennesker er nået til at blive mere restriktive over for opfordringer til at blive venner på Facebook. 
Det nærliggende spørgsmål er derfor: Hvad kommunikerer de mange venner med hinanden om? Det drejer sig om, at mange skriver såkaldte statusopdateringer om stort og småt i det fortløbende liv, hvorfor grundtonen i indholdet som regel er let og underholdende. Kommunikationen får karakter af small talk, altså fatisk kommunikation, der godtgør, at man er til stede for den anden. Facebook fungerer imidlertid sådan, at den enkelte ikke kan være sikker på, at hendes eller hans statusopdateringer faktisk når hele vennekredsen. Det forklarer Jesper Tække i artiklen "Facebook og social ambivalens":

\footnotetext{
"Hvor mange venner, og hvem der vil se ens opslag i deres nyhedsliste, bliver styret af algoritmen EdgeRank, der ikke i sine selektionskriterier er offentlig tilgængelig. [...] mange lever med den falske bevidsthed, at alle ens venner vil se, hvad de skriver [...] ligesom tredjepartsselskaberne kan betale for at få deres statusopdateringer i fleres nyhedsliste. [...]så [der]vil blive endnu mindre plads til ikkebetalende statusopdateringer." (p. 81)
}

Small talk er udbredt mellem f.eks. eleverne i dagens gymnasium, og det konstateres, at de nye medier bliver anvendt for lidt i fagene. Eleverne bruger medierne til at koble sig af undervisningen. Derfor bør lærerne anvende de sociale medier i undervisningen, hedder det. Det vil givet være et fremskridt, men Facebook og andre teknologier sikrer næppe hverken elevernes opmærksomhed eller læring. Teknologierne kan bidrage og gør det allerede i et vist omfang. Lærernes autoritet udfordres, og det er på mange måder en gentagelse. Allerede de elektroniske medier, radio og tv, udfordrede lærernes autoritet med ophævelsen af deres monopol på viden og med det resultat, at de elektroniske medier skabte mere ligestilling og retfærdighed i samfundet (p. 75). Det er skrevet med reference til den amerikanske kommunikationsforsker Meyrowitz og modificeres med, at det tog tid, og at kvindekamp og ungdomsoprør nok også spillede ind.

Hvis eleverne i folkeskolen skal have karakteren 4 for at komme i gymnasiet, klarer teknologien det ikke for dem. Det mener Jesper Tække nok heller ikke, men den teknologiske determinisme er farlig at henvise til I et gammelt Anders And-blad fra 1950'erne erklærede Rip, Rap og Rup således, at de ikke var blevet bedre til dansk stil til trods for deres nyerhvervede skrivemaskiner.

Den enkelte formulerer sig altså op imod en broget og delvis ukendt samling venner på Facebook. Det har naturligt rejst spørgsmålet om god opførsel i henvendelserne. Der foreligger ikke nogen vedtagelse om spørgsmålet, men Anne Skot Sørensen beretter dog om, at upassende tale om sygdom, død, kropslige defekter, kærestesorger, seksuelle handlinger og aggressiv omtale af tredje person alle er elementer i den uønskede kommunikation ( $p$. 129). Nogle videresender nyheder eller andet indhold fra internettet og bliver på den måde troværdige gatekeepere for vennekredsen, så aktuelle politiske kommentarer eller tænksomme videoer fra YouTube får modtagerne til at tænke videre med dem.

Handlinger indgår imidlertid også indgået i de sociale mediers virkelighed. Det drejer sig især om organiseringer via Facebook og andre sociale medier i forbindelse med demonstrationer, oprør og parlamentariske valghandlinger. Det arabiske forår 2010-2011, burmesiske 
munkes oprør mod militærdiktaturet i 2007, opstanden i Iran i 2009, Obamas valgkampagner samt folketingsvalgene i 2007 og 2011 er blandt de kendte eksempler på de sociale mediers involvering.

Henrik Bødker gør i sin artikel opmærksom på det centrale, at "[...] meget af det, der før var uformelt og mundtligt, nu efterlader sig tekstlige spor." (p. 212). Det betyder, at modstanderne, oftest myndigheder af forskellig slags, får nye muligheder, som Jakob Linaa Jensen anfører: "Nok blev medierne brugt i forbindelse med koordinering af opstandene i Iran i 2009 og Egypten i 2010. Men data fra de selvsamme medier gjorde myndighedernes efterfølgende sporing og forfølgelse af demokratiaktivisterne meget nemmere."(p. 204).

På Facebook kan vi alle overvåge vennernes "færden" og formuleringer, hvorfor nogle unge er stået af, så deres ungdomsliv ikke ligger helt synligt for f.eks. forældrene. Facebook bliver på en måde et Foucault-panoptikon med gensidige overvågningsrelationer. I antologiens sidste artikel behandles virksomhedernes krisekommunikation i en virkelighed med Facebook. Det vises, at der kan opstå en "netværksbåret offentlighed", når mange brugere på Facebook udfordrer den kriseramte virksomhed, så den bliver nødt til at reagere (p. 263).

Som helhed rummer bogen en række interessante artikler om Facebooks historie, om danskernes aktiviteter på Facebook og om en række ambivalenser, der følger med livet på Facebook, herunder uklarheden om, hvem og hvor mange der faktisk får den enkeltes statusopdateringer at se. I en anden stor afdeling behandles venskaberne og spørgsmål om identitetsdannelse som Facebook-bruger samt kommunikationsetikken. Endelig behandles Facebook som et medie med politiske indflydelsesmuligheder ved bestemte begivenheder og som led i den løbende nyhedsstrøm. Flere af artiklerne bygger på original forskning indsamlet via surveys, deltagende observationer, gruppe- og enkeltinterviews. Det er også værd at fremhæve, at relevante teoretiske forfattere i udstrakt grad er integreret i artiklerne, så bogen må have interesse og muligheder for anvendelse som introduktion for studerende på især gymnasierne, men også på professionshøjskolerne og måske endda på universiteterne. Der er kort sagt tale om en spændende bog om Facebook.

Oluf Danielsen,
Lektor, dr.phil.
Institut for Kommunikation, Virksomhed og Informationsteknologier
Roskilde Universitet
oluf@ruc.dk

